\title{
RAPID METHOD FOR DETERMINING FAT CONTENT IN MEAT BY USING CONTINUOUS WAVE NUCLEAR MAGNETIC RESONANCE (CW-NMR) TECHNIQUE
}

\author{
E. NAGY, J. CZEGLÉDI-JANKÓ, I. ÉLIÁS and L. KÖRMENDY \\ Hungarian Meat Research Institute, 1097 Budapest, Gubacsi út 6/b. Hungary
}

(Received: 6 March 2000; accepted: 1 June 2000)

\begin{abstract}
Development of rapid methods is often needed for the in-line process control of the proximate composition (e.g. fat or moisture content) of meat in the meat processing plants. This paper reports on the continuous wave nuclear magnetic resonance (CW-NMR) technique applied for determining fat content in fresh meat. The interfering moisture content in meat was removed by microwave drying and the dried residue was transferred quantitatively into the NMR-tubes. The total analysis time was about $35 \mathrm{~min}$. Experiments were performed with pork (with a fat content from $1.7 \%$ to $21 \%$ ), beef (with a fat content from $1.0 \%$ to $16.1 \%$ ), lard (rendered pork fat) and tallow (rendered beef fat) samples and with their combinations: lard-tallow, lard-lean pork, tallow-lean beef and lard-tallow-lean beef-lean pork.

The regression (prediction) equations (NMR-signal vs. fat content determined with the Soxhlet reference method) of pork and beef did not differ significantly. However, there was a noticeable difference between the regression lines of pure lard and pure tallow. Moreover, the latter ones differed from the regression equations of pork, beef and of the various meat-fat combinations. The variability of the fatty acid composition of the fat also seems to influence the stability of the calibration curves, because the sensitivity of the CW-NMR signal to the fatty acid composition interferes with the quantitative determination of fat content in meat.
\end{abstract}

Keywords: CW-NMR, fat determination, meat analysis, NMR

The common rapid methods for determining the proximate composition of meat used for the in-line process control are either time-consuming or often unreliable. Various instrumental methods have been used to determine the fat content of meat and meat products (X-ray, near infrared reflectance, NMR etc.). Nuclear magnetic resonance spectrometry, as a rapid and simple method, has been used for long in the Hungarian oil and confectionary industry (KÖVÁRI, 1990). There are two types of instrument for analytical purposes: continuous wave (CW-) and pulsed (P-) NMR.

The CW-NMR studies of NILSSON and KOLAR (1971) showed that, in spite of the close relationship between CW-NMR signal and fat content, the NMR technique gave a 
$0.3 \%$ higher fat content than the reference method in meat products. CASEY and MILES (1974) measured the fat content of lean meat by NMR and established that a linear relationship exists between NMR signal and fat content, with residual standard deviations (RSD) $0.2 \%$ and $0.16 \%$ for total and extractable fat, respectively.

RENOU and co-workers (1985) applied P-NMR spectrometry to estimate the fat content in meat. The results of chemical analysis correlated well with the NMR data, the mean standard deviation of the difference was $0.8 \%$.

Later, RENOU and co-workers (1987) determined the fat and moisture content of pork and beef by a "home built" P-NMR spectrometer. The ratios of the respective NMR peaks correlated closely with the results obtained by the standard chemical analysis, however, different fats produced different $-\mathrm{CH}_{2}$ - signal intensities with a mean error of cca. $1 \%$.

The objective of the present work was to assess the precision and "trueness", formerly called "accuracy" (INTERNATIONAL STANDARD, 1994), of the CW-NMR technique for the fat content in fresh meat.

\section{Materials and methods}

The measurements were performed with 24 post rigor pork samples (loin and ham, with fat content ranging from $1.6 \%$ to $21 \%$ ) and 16 post rigor beef samples (loin and round, with fat content ranging from $1 \%$ to $16.1 \%$ ). Furthermore, three different meat-fat mixtures were also prepared:

- lean pork mixed with lard (rendered pork fat), with a fat content from $2 \%$ to $30 \%$,

- lean beef mixed with tallow (rendered beef fat), with a fat content from $1 \%$ to $25 \%$,

- mixtures of lean pork-lean beef $(1: 1)$ - lard-tallow (1:1), with a fat content from $1.5 \%$ to $30 \%$.

- The relationship between NMR-signal and quantity of fat was investigated with lard, tallow and with a lard-tallow mixture $1: 1$.

The measurements were made with the CW-NMR spectrometer Newport Analyser (type MK IIIA) using a $40 \mathrm{~cm}^{3}$ sample tube. After careful homogenization in Moulinex apparatus, $20.00 \mathrm{~g}$ of the sample unit was dried in microwave oven for about 23 min (NAGY et al., 1991). The dried residue was then transferred quantitatively into the NMR-tubes. Prior to NMR analysis, the fats were dehydrated with anhydrous $\mathrm{Na}_{2} \mathrm{SO}_{4}$. The measurements were performed at $25^{\circ} \mathrm{C}$. The $\mathrm{CW}-\mathrm{NMR}$ signal was obtained in 2-3 s. Results obtained with the NMR-technique were compared with the fat content obtained by Soxhlet extraction (HUNGARIAN STANDARD, 1985). 


\section{Results}

Calculations (CW-NMR signal vs. the Soxhlet reference method) were performed with the help of the classic regression analysis (HALD, 1962). Results are presented in Tables 1 and 2.

Table 1

Results of regression analysis $(\hat{y}=a+b \cdot x)$

\begin{tabular}{ccccc}
\hline Serial number & $\begin{array}{c}\text { Amount of fat (g) in 20 g } \\
\text { sample unit (range) }\end{array}$ & $\mathrm{n}$ & $\mathrm{b}$ \\
\hline 1 & $0.337-4.153$ & 24 & 0 & 4.543 \\
2 & $0.123-3.220$ & 16 & 0 & 4.641 \\
$3^{\mathrm{a}}$ & $0.613-8.013$ & 5 & 0 & 5.353 \\
$4^{\mathrm{a}}$ & $0.728-12.165$ & 5 & 0 & 4.400 \\
5 & $0.403-6.233$ & 14 & 0 & 4.915 \\
6 & $0.150-5.867$ & 14 & 1.04 & 4.553 \\
$7^{\mathrm{a}}$ & $0.232-6.054$ & 7 & 0 & 4.768 \\
8 & $0.323-6.320$ & 14 & 0 & 5.248 \\
\hline
\end{tabular}

n: sample size, a: intercept, b: slope

1. Pork sample. 2. Beef sample. 3. Lard (rendered pork fat). 4. Tallow (rendered beef fat). 5. Mixture of lean pork with lard. 6. Mixture of lean beef with tallow. 7. Mixture of lard with tallow (1:1). 8. Mixture of lean pork-lean beef $(1: 1)$ with lard-tallow $(1: 1)$

a indicates the amount of fat $(\mathrm{g})$ transferred into the NMR-tubes.

Table 2

Comparison of slopes (b) with the Student's t-test. (The serial numbers are listed below Table 1)

\begin{tabular}{cccccccc}
\hline Serial numbers & 1 & 2 & 3 & 4 & 5 & 6 & 7 \\
\hline 1 & & & & & & \\
2 & $\mathrm{NS}$ & & & & & \\
3 & $\mathrm{~S}$ & $\mathrm{~S}$ & & & & \\
4 & $\mathrm{NS}$ & $\mathrm{S}$ & $\mathrm{S}$ & $\mathrm{S}$ & $\mathrm{S}$ & & \\
5 & $\mathrm{~S}$ & $\mathrm{~S}$ & $\mathrm{~S}$ & $\mathrm{~S}$ & $\mathrm{~S}$ & \\
$6^{\mathrm{a}}$ & $\mathrm{S}$ & $\mathrm{S}$ & $\mathrm{S}$ & $\mathrm{S}$ & $\mathrm{S}$ & $\mathrm{S}$ \\
7 & $\mathrm{NS}$ & $\mathrm{NS}$ & $\mathrm{S}$ & $\mathrm{S}$ & $\mathrm{NS}$ & $\mathrm{S}$ & \\
8 & $\mathrm{~S}$ & $\mathrm{~S}$ & $\mathrm{NS}$ & $\mathrm{S}$ & $\mathrm{S}$ & $\mathrm{S}$ & \\
\hline
\end{tabular}

S: significant difference $(\alpha<0.05)$. NS: no significant difference.

${ }^{a}$ Indicates that the intercept (a) is significantly different from 0 (see also Table 1) 
The evaluation of data (KÖRMENDY et al., 1989) showed that the relations presented in Table 1, except sample with serial number 6, can be described with the $\hat{y}=b \cdot x$ equation, i.e. proportional relationships exist between CW-NMR signal (y) and fat content measured with the Soxhlet method (x). In Table 2, the slopes of the different regression lines were compared by Student's $t$-test (HALD, 1962). As shown in Tables 1 and 2:

- The slopes (b) of pork (1) and beef (2) are not significantly different.

- The slopes (b) of pork (1), lard (3), and pork-lard mixture (5) differ significantly, however, the difference in the slopes (b) of lard (3) and porklard mixture (5) is not too large.

- The differences in the slopes (b) of beef (2), tallow (4) and beef-tallow mixture (6), however significant, are small.

- The intercept (a) of equation with serial number 6 differs, for unknown reasons, significantly from 0 .

- Comparing the slopes (b) of pure lard (3) with pure tallow (4), it is apparent that the slopes (b) differ significantly and considerably.

- The slopes (b) of the regression lines of the meat-fat mixtures $(5,6$ and 8$)$ differ significantly, too.

\section{Conclusions}

As might be expected, despite the removal of water, there are interactions between fat and the other components of meat, because the regression (prediction) equations of the pure rendered fats, of the meat-fat mixtures and those of meats differ significantly and considerably.

Comparing the equations of lard and tallow, it appears that the essential difference in their fatty acid composition has a considerable influence on the CW-NMR signal. For this reason, the stability of the regression lines, which can be considered as calibration curves (also called prediction equations), is questionable. It has long been known that the fatty acid composition (e.g. proportion of unsaturated fatty acids, length of aliphatic chains) varies with the type of fat (e.g. beef or pork), with the animal feed composition, as well as with the anatomical location (SZEREDI \& PERÉDI, 1956). All these interfering factors contribute to the complexity of results presented in this study. RENOU and co-workers (1987) also observed that the different fat types may lead to an a NMR signal intensity error of about $1 \%$, however, in their opinion, this error is still acceptable. 
The regression (prediction) equations of pork and beef do not differ significantly. On the other hand, the equations obtained with the pork-lard and beef-tallow mixtures deviate considerably from the former ones. For this reason, the CW-NMR technique, at these conditions, cannot be used for assessing the fat content of pork-beef mixtures. Even in the case of pure pork or pure beef, the stability of the prediction equations is questionable. Namely, the systematic changes which occur in the chemical composition of fats, even of the same origin, may induce a noticeable bias in the prediction of the fat content compared with the Soxhlet reference method.

This research work has been sponsored by OTKA (National Scientific Research Foundation, Budapest) under project number T 022231.

\section{References}

CASEY, I. C. \& MILES, C. A. (1974): Determination of the fat content of meat using nuclear magnetic resonance. J. Sci. Fd Agric., 25, 1155-1161.

HALD, A. (1962): Statistical theory with engineering applications. J. Wiley \& Sons, New York, pp. 633-635.

HUNGARIAN STANDARD (1985): Húskészítmények vizsgálati módszerei. Zsírtartalom meghatározása. (Measurement methods for meat products. Determination of fat content.) MSZ 5874/2.

INTERNATIONAL STANDARD (1994): Accuracy (trueness and precision) of measurement methods and results. Part 1: General principles and definitions. ISO 5725-1.

KÖRMENDY, L., MiHÁLYI, V., ZUKÁL, E. \& CSIBA, A. (1989): Comparison of analytical methods. Meat Sci., 26, 193-199.

KÖVÁRI, K. (1990): A zsírtartalom közvetlen meghatározása szilárd állapotban pulzáló NMR-készülékkel. (Direct determination of the fat content in solid state by pulsed NMR-instrument). Olaj, Szappan, Kozmetika, 39, 105-110.

NAGY, E., KÖRMENDY, L. \& CZEGLÉDI-JANKÓ, J. (1991): Hús és húskészítmények nedvességtartalmának meghatározása "Ultra-X" mikrohullámú készülékkel. (Determination of moisture content of meat and meat products by microwave oven "Ultra-X"). A Hús, 1, 29-31.

NILSSON, R. \& KOLAR, K. (1971): The determination of fat content in meat and meat products by nuclear magnetic resonance. Proc. 17th European Meeting of Meat Research Workers, Bristol. Manuscript. pp. 299-303.

RENOU, J. P., KOPP, I. \& VALIN, C. (1985): Use of low resolution NMR for determining fat content in meat products. J. Fd Technol., 20, 23-29.

RenOU, J. P., BRiguet, A., GATEllieR, PH. \& KoPP, J. (1987). Determination of fat and water ratios in meat products by high resolution NMR at 19.6 MHz. Int. J. Fd Sci. Technol., 22, 169-172.

SZEREDI, I. \& PERÉDI, J. (1956). Sertészsír vizsgálatok. (Studies on pork fat). Élelmezési Ipar, 8, $253-257$. 